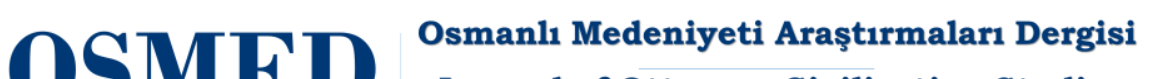 Journal of Ottoman Civilization Studies

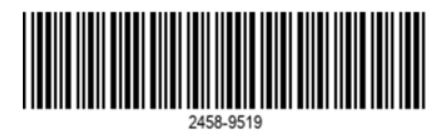

\section{Padişah Çocuklarının Doğumu Üzerine Bir İnceleme: Sultan Abdülaziz'in Velâdeti \\ A Review of the Birth of the Sultan's Children: The Birth of Sultan Abdülaziz}

\author{
Nermin Genç \\ İstanbul Üniversitesi \\ Tarih Bölümü \\ ngencnermin@gmail.com
}

ORCID ID : 0000-0002-8285-8793

\section{Makale Bilgisi / Article Information}

Makale Türü / Article Type : Araştırma Makalesi

Geliş Tarihi / Received : 9 Mayıs 2021

Kabul Tarihi / Accepted : 15 Haziran 2021

Yayın Tarihi / Published : 15 Ekim 2021

DOI Number : 10.21021/osmed.935273

\begin{abstract}
$*$
Teşekkür:

"Makaleyi okuyup değerlendiren kıymetli hocam Prof. Dr. Zeynep Tarım’a teşekkür ederim."<smiles>[CH]</smiles>

\section{Kaynak Gösterme / Citation}

Genç, N. “Padişah Çocuklarının Doğumu Üzerine Bir İnceleme: Sultan Abdülaziz' in Velâdeti". Osmanlı Medeniyeti Araştırmaları Dergisi, 13 (2021): 60-82.
\end{abstract}




\title{
Padişah Çocuklarının Doğumu Üzerine Bir İnceleme: Sultan Abdülaziz'in Velâdeti
}

\author{
A Review of the Birth of the Sultan's Children: The Birth of Sultan Abdülaziz
}

\section{Nermin Genç}

$\ddot{O} z$

Osmanlı Devleti'nde veladet-i hümayun adı verilen padişah çocuklarının doğumları hem saray hem de halk arasında büyük sevinçlerin yaşanmasına ve çeşitli eğlencelerin tertip edilmesine neden olurdu. Doğum vesilesiyle insanlar dağıtııırdı. Bu makalede bir padişah çocuğunun aynı zamanda ileride padişah olacak olan Sultan Abdülaziz'in doğumu ele alınmıştır. Şehzade ve sultanların doğumu, doğum sonrasında yapılan adetler, şehzade ve sultan doğumlarının ne şekilde gerçekleştiği ve halka nasıl duyurulduğu hakkında bilgiler verilmiştir. Osmanlı Devleti'nde şehzade ve sultan doğumlarının öneminden bahsedilerek örnekler verilmiş ve merasimlerde uygulanan bazı teşrifat değişikliklerinden söz edilmiştir. Makalenin konusunu oluşturan Sultan Abdülaziz'in doğum tarihi, doğum yeri hakkında bilgiler verilmiş ve Sultan Abdülaziz'in doğumuna düşürülen tarihler gösterilmiştir. Sultan Abdülaziz'in doğumu sırasında ve doğum sonrasında yapılan işlemler ayrıntılarıyla ele alınmıştır. Daha sonra Sultan Abdülaziz'in doğumundan sonra verilen hediyeler, dağıtılan bahşişler ele alınmakta, şehzadenin doğumundan sonra alınan el izi bu çerçevede konu içinde yer almaktadır.

Anahtar Kelimeler: Abdülaziz, 19. yüzyıl, Saray, Velâdet-i Hümâyun, Teşrifat.

\section{Abstract}

In the Ottoman Empire, the birth of sultan's children, which is called veladet-i hümayun, would cause great elation among the palace and people and the organisation various entertainments. Due to the birth, gifts were alloted. In this article, a child of sultan, Sultan Abdülaziz who would also become a sultan in the future, is discussed. Information is given about the birth of princes and sultans, the customs after their birth, in what way the birth of princes and sultans occur and how they were announced to the public. It is mentioned about the changes in ceromonials, which were implemented in the ceremonies, and some examples are given by referring to the importance of the birth of princes and sultans in the Ottoman Empire. Information is given about Sultan Abdülaziz's date of birth and place, which is the main subject of this article, and the dates related to the birth of Sultan Abdülaziz have been demonstrated. The procedures applied along and after the birth of Sultan Abdülaziz have been discussed in details. Then, the gifts and the baksheesh alloted after the birth of Sultan Abdülaziz are discussed, and the handprint taken after the birth of prince is included in this framework.

Keywords: Abdülaziz, 19th. Century, Palace, Birth Ceremony, Ceremonies, Tradition. 


\section{Giriş}

Osmanlı padişahlarının doğumlarıyla ilgili yapılan ritüellerin tamamı velâdet-i hümâyun merasimi adı altında toplanırdı. Bu çerçevede Osmanlı hanedan ailesinde dünyaya gelen şehzade ve sultanlar için doğumun ilan edilmesi, oda hazırlanması, lala ve dayeler tayin edilmesi gibi işlemler yapılırdı. Padişah çocuklarının doğumu hanedanın devamını sağlayacağı için özel günlerden biri sayılır ve şehzade ve sultan doğumları bir teşrifat çerçevesinde törenlerle kutlanırdı. Bu kutlamalar sadece saray içerisinde değil halk arasında da gerçekleşirdi. Çeşitli eğlenceler tertip edilir, top ve tüfek atışları yapılarak şehzade veya sultan doğumu kutlanırdı.

Arşiv kaynaklarında ve bazı kroniklerde padişah çocuklarının doğumu ile ilgili bilgiler yer almaktadır. Topkapı Sarayı Müzesi Arşivi’nde yer alan Ceyb-i hümâyun ve Harc-ı hassa defterleri de arşiv kaynaklardan biri olup padişah çocuklarının doğumlarında nerelere ve kimlere ne miktarlarda harcama yapıldığı hususunda teferruatlı bilgiler ihtiva etmektedir. Bu defterler vasıtasıyla Sultan Abdülaziz'in doğumundan sonra gerçekleştirilen kaidelerle de ilgili bilgiler bulmak mümkündür. Bu makalede ağırlıklı olarak arşiv kaynaklarından ve kroniklerden yararlanılarak Sultan Abdülaziz'in doğumu ele alınmış ve Abdülaziz'in doğumundan sonra uygulanan teşrifat ile ilgili bilgiler sunulmuştur.

Osmanlı Devleti'nde gerek saray içerisinde gerek saray dışındaki insanlar arasında gerçekleşen her türlü törensel davranışlar biçimine teşrifat adı verilirdi. Şehzade ve sultan doğumları, beşik alayı, bed-i besmele töreni, cülus merasimleri, kılıç alayı, bayram merasimleri, şehzade ve sultan dügünleri, sünnet merasimi, surre alayları, göç ü hümâyun, biniş-i hümâyunlar, elçi kabulü, divan toplantıları, askerlere maaş tahsisi vs. genellikle teşrifat kurallarına riayet edilerek gerçekleşirdi ${ }^{1}$.

Osmanlı Devleti'nde şehzade ve sultan doğumlarının ehemmiyeti büyüktü. Hanedan soyundan bir şehzadenin doğumu hanedanlığın devamı ve devletin bekası için son derece kıymetliydi. Şehzade doğumları da teşrifat kuralları çerçevesinde gerçekleştirilen törenlerle kutlanırdı. Şehzadelerin doğumu ve doğumundan sonra uygulanan teşrifatlardan bazıları şöyleydi:

\section{Velâdet-i Hümâyun}

Osmanlı Devleti'nde padişahın kadınlarından birinin bir çocuk dünyaya getirmesi Devlet-i ‘Âliyye'nin en mesut günlerinin yaşanmasına vesile olan kutlu bir gün olarak addedilirdi. Çocuk doğmadan önce kız olsun erkek olsun fark gözetilmeden doğum öncesi hazırlıklara başlanır, valide sultan bununla bizzat ilgilenirdi ${ }^{2}$. Velâdet-i hümâyun adı verilen padişah çocuklarının doğumu, XVII. yüzyıldan itibaren bazı merasimlerle kutlanırdı ${ }^{3}$. Sarayda doğan şehzade ve sultanlara verilen kıymet nispeten aynı olmasına karşılık, şehzade doğumlarından sonra yapılan teşrifatta ufak değişiklikler göze çarpmaktadır.

XVII. yüzyıldan itibaren şehzade ve sultan doğumları bir hatt-1 humâyunla sadrazama bildirilirdi. Doğan çocuk kız ise saraydaki yüksek rütbeli bir görevli hatt-1 hümayunu sadrazama götürür, doğan çocuk erkek ise hatt-1 hümayun Darüssaade ağası tarafından sadrazama teslim edilirdi. Bu haberin alınması üzerine sadrazam, vezirler, şeyhülislam, kazaskerler, yeniçeri ağası ve diğer devlet ricali saraya giderek

1 Zeynep Tarım, "Osmanlı İstanbul'unda Merasim ve Teşrifata Dair Kaynaklar", Türkiye Araştırmaları Literatür Dergisi 8/XVı (2010): 131-133.

2 Funda Acar, "Osmanlıda Padişah Oğulları ve Kızlarının Eşitlendiği Alan: Teşrifat", Hitit Üniversitesi Ilahiyat Fakültesi Dergisi 14/XXVII (2015): 189-190.

3 İsmail Hakkı Uzunçarşılı, Osmanlı Devletinin Saray Teşkilâtı, (Ankara: TTK, 1988), 168. 
tebrikleri kabul edilir, onlara kürk ve hilat giydirilirdi. Doğumdan sonra devlet ricaline loğusa şerbeti gönderilir ve bunların eşleri, baltacı vasıtasıyla saraya davet edilirdi ${ }^{4}$.

XIX. yüzyıl kaynaklarına göre Osmanlı Devleti’nde hükümdarın erkek veya kız çocuğu dünyaya geldiğinde ilk önce kızlar ağasının oda lalası silahtar ağaya haber verir, silahtar ağa da bu müjdeli haberi veren oda lalasına bir bohça içinde hediyeler takdim ederdi. Daha sonra silahtar ağa saray maiyetine şehzade veya sultan doğumunu haber verirdi. Enderun'da bulunan her odada, doğan çocuk şehzade ise beş, sultan ise üç adet kurban kesilerek Matbah-1 Âmire'ye gönderilirdi. Doğan çocuk erkek ise yedi gün boyunca beş pare, kız ise beş gün boyunca üç pare top atışı yapılarak padişah çocuklarının veladeti kutlanırd ${ }^{5}$. Padişahın yeni doğan çocuğuna valide sultan ve sadrazam tarafından mücevherlerle süslenmiş beşik hediye etmek de doğum sonrası gerçekleştirilen gelenekler arasında sayılıyordu.

\section{Doğum Sonrası Verilen İhsanlar}

Bir XIX. yüzyıl kaynağına göre velâdetin gerçekleşmesinden sonraki ilk Cuma günü padişahın gittiği camiide bulunan imamlar velâdet duası eder ve padişah da onlara mevsimine göre ferve-i semmûr veya kâkum gibi hil'atler ihsan ederdi' .

Şehzade doğumları sarayda büyük sevinçlere yol açardı zira bu doğum hanedanın devamlılığı demekti. Şehzade doğuran kadın mertebe olarak yükselir, kendisine çeşitli ihsanlarda bulunulur ve bazı ayrıcalıklar kazanırd1 $^{7}$. Saraydaki koğuşlar da çok güzel süslenir, avize ve aynalarla donatılır, sazlı sözlü eğlenceler düzenlenir, hokkabazlar, hayalbazlar, meddahlar gösteri yapardı. Koğuştaki ağalara cirit, mızrak ve tomak oyunları oynattır1lip atiyeler verilirdi ${ }^{8}$.

Şehzade ve sultan doğumları önemli bir hadise sayılırdı. Nitekim bu doğumla birlikte çoğu insan ihsan ve mazhara nail oluyordu. Bunlardan biri de şairlerdi. Bazı şairler şehzade veya sultan doğumunu haber aldıklarında hemen bir tarih düşürüyorlar ve kasideler kaleme alıyorlar böylece birçok ihsan ve inam elde etmiş oluyorlardi ${ }^{9}$.

Sarayda şehzade ve sultan doğumları saraydaki bazı görevlilerin de ihsan almasına vesile oluyordu. Mesela III. Mustafa'nın (1757-1774) oğlu şehzade Mehmed'in veladetinde haseki ağaya, has ahır halifesine, kozbekcibaşına 40'ar kuruş ihsan verilmiştir ${ }^{10}$. I. Abdülhamid'in (1774-1789) kızı Melekşah ${ }^{11}$ $(28 \text { Ocak 1781) })^{12}$ dünyaya geldiği zaman hasodalı ağalara 1000, çukadar ağaya 250, rikabdar ağaya 200, hazine kethüdasına 250, kiler ve seferli kethüdaları 300 kuruş olmak üzere toplam 2.900 kuruş ihsan

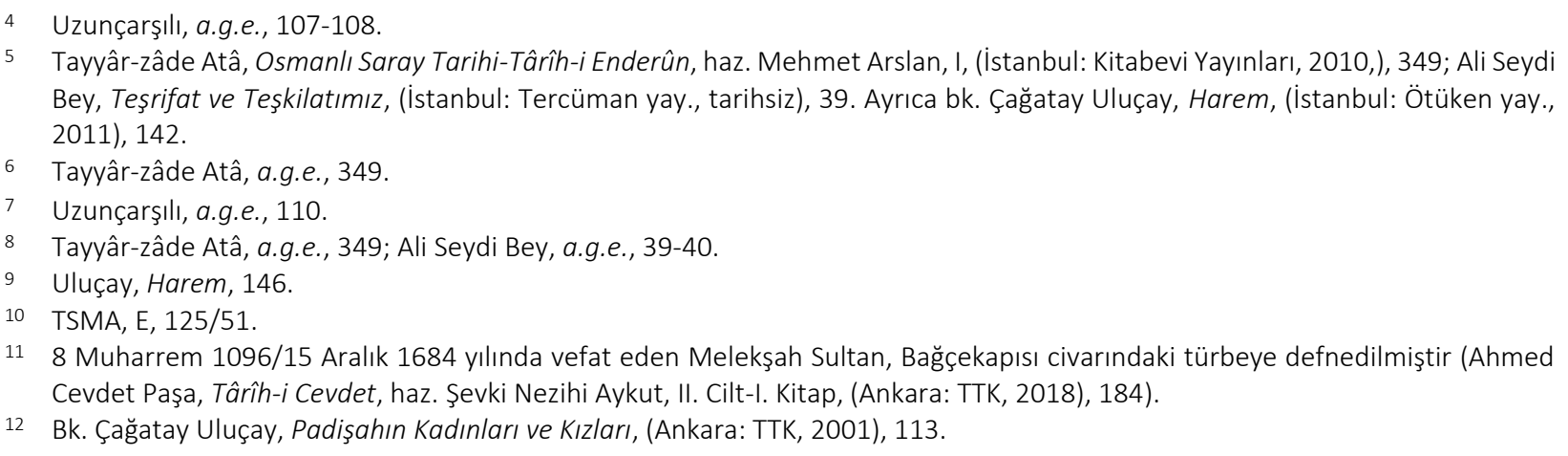


edilmiştir ${ }^{13}$. II. Mahmud'un (1808-1839) şehzadesi Murad'ın veladetinde ise (24 Kasım 1811) pehlivan ve duaciya 167,5 kuruş ihsan edilmiştir ${ }^{14}$.

Osmanlı Devleti'nde sarayda veladet-i humâyunlarda bazı kişilere verilen ihsanlar da veladet boyunca yapılan etkinlikler hakkında ipucu vermektedir. Mesela; II. Mahmud'un kızı Mihrimah Sultan'ın (29 Haziran 1812) ${ }^{15}$ veladetinin ilk gününde enderun ağalarına 2000 kuruş, veladet-i hümayun hitamında ise enderun mehterlerine 400, birun mehterlerine 400, çengilere 200, köçeklere 40, Müslüman hanendelere 91, zımmi hanendelere 81, hayalbazanlara 40, meddahlara 30, yalancılara 10, kuklabazana 10, babalı ve oğullu kullara 10, şairanlara 25, kıptiyan çalgıcılara 10 kuruş ihsan verilmiştir ${ }^{16}$. II. Mahmud'un diğer şehzadesi Bayezid'ın doğumunda ise (Mart-Nisan 1812) kilar ve seferli kethüdaları ağalarına 120 kuruş, dülbend, miftah ve peşkir ağalara 120 kuruş, enderun ağavatına 5500 kuruş ihsan verilmiştir ${ }^{17}$. II. Mahmud'un bir başka şehzadesi Abdülhamid (Mart-Nisan 1813) adlı şehzadenin veladetinin hitamında ise enderun mehterlerine 400, birun mehterlerine 400, Müslüman hanendelere 91, zımmi hanendelere 81, hayalbazanlara 40 , meddahlara 30 , yalancılara 10 , kuklabazanlara 10, babalı oğullu kullara 10, şairanlara 2 , perdebazan ve hokkabazlara 20 , kıptiyan çalgıcılarına 10 kuruş $^{18}$ ihsan verilmiştir. Bu bilgilerden hareketle velâdet-i hümâyun sonrasında, sazendeler ve hanendelerin, meddahların, hayalcilerın, meddahların, kuklacıların, hokkabazların gösteriler yaparak saray halkını eğlendirdiğini ve bu sayede birçok görevlinin ihsan almasına vesile olduğu anlaşılmaktadır.

\section{Doğumun Halka Duyurulması}

Osmanlı Devleti'nde padişah çocuklarının doğumu İstanbul'un tüm sokaklarında bağırarak duyuru yapan dellâllar vasıtasıyla ve Topkapı Sarayı'nın deniz kıyısında yer alan toplardan top atışı yapılmak suretiyle halka duyurulurdu. Genellikle şehzade doğumlarında beş, sultanların doğumunda üç pare top atış1 yapılırd1. Ancak sarayda uzun zaman sonra ilk defa bir hanedan çocuğu doğmuşsa, doğan çocuk kız veya erkek olsun beş pare top atışı yapılırd1 ${ }^{19}$. Doğum haberi Osmanlı Devleti'nin diğer büyük eyaletlerine de gönderilir ve bu haber şer'i mahkemelerde sicillere işlenirdi ${ }^{20}$.

Doğum haberini alan halk sevinç gösterilerinde bulunurdu. Şehzade ve sultan doğumları, tertip edilen eğlence ve şenliklerle kutlanırdı ${ }^{21}$. Fener ve fanuslarla donatılan tüm İstanbul'da halk gönüllerince eğlenirdi. Doğum için yapılan şenlikler 5 ila 7 gün arasında değişmekteydi2 ${ }^{22}$ Bu şenlikler padişahın ilk erkek çocuğu ise daha fazla gün donanma yapılarak kutlanır, diğer çocuklarda azalırd ${ }^{23}$. Mesela I. Ahmed'in (1603-1617) oğlu şehzade Osman [II. Osman] 4 Kasım 1604'de dünyaya geldiğinde yedi gün yedi gece şehir donanması yapılması için ferman buyrulmuş²4, IV. Mehmed'in (1648-1687) şehzadesi

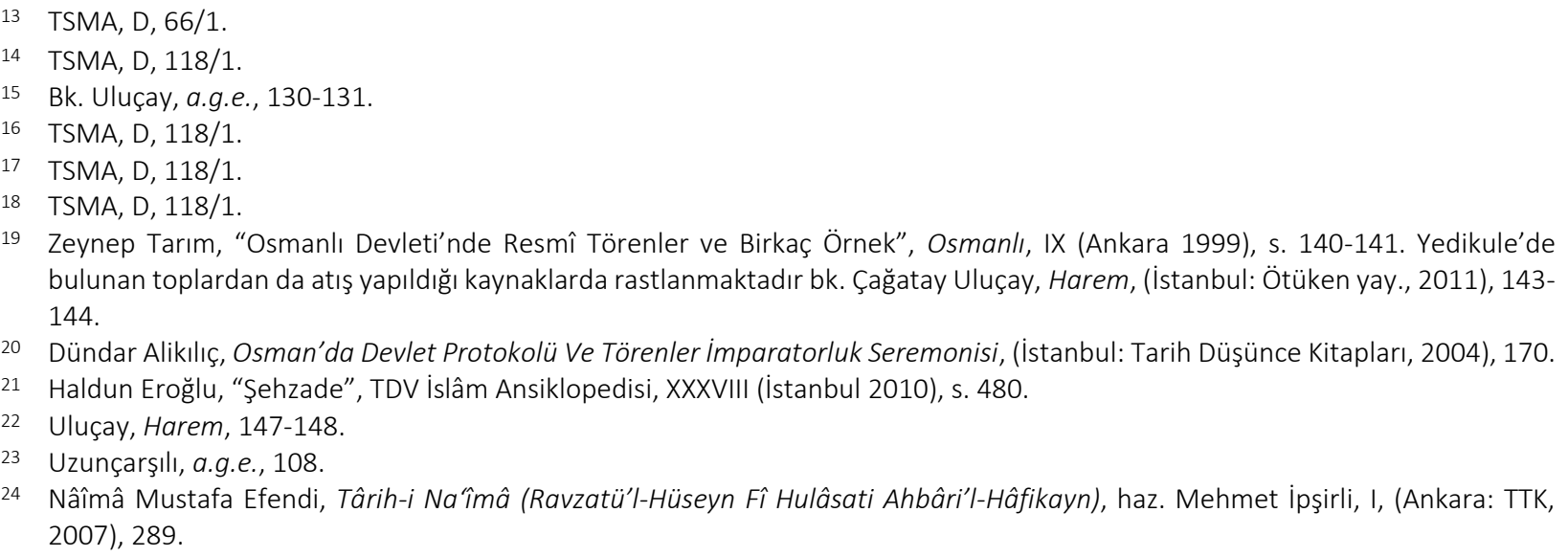


Mustafa 2 Haziran 1664'de dünyaya geldiğinde şehirde yedi gün yedi gece donanma tertip edilirken ${ }^{25}$ IV. Mehmed'in 31 Aralık 1673 yılında doğan şehzadesi Ahmed için üç gün üç gece donanma düzenlenmesi emri verilmiştir ${ }^{26}$. 6 Ekim 1692 yılında II. Ahmed'in (1691-1695), İbrahim ve Selim adında iki şehzadesi doğduğunda memalik-i mahrûsada üç gün üç gece donanma tertip edilmiştir ${ }^{27}$. Ayrıca III. Mustafa'nın (1757-1774) ilk çocuğu kız olmasına rağmen çok uzun bir zaman sonra ilk defa hükümdar çocuğu doğduğu için (Hibetullah Sultan: 13 Mart 1759) yedi gün yedi gece kutlama yapılması için emir vermiş fakat halkın çok mutlu olup eğlendiklerini gördükten sonra kutlamaları on güne çıkarmış şehir de on gün on gece süren şenlikler yapılmıştır ${ }^{28}$. Bu şenliğin uzun sürmesinde sarayda kırk yıldan beri şehzade ve sultan doğmayışının etkisi büyüktür ${ }^{29}$.

Osmanlı Devleti'nde gerçekleşen velâdet-i hümâyunlar hanedan için büyük bir önem arz etmekteydi ki zira bu doğumlar hanedanın devam edeceği anlamına geliyordu. Uzun süre sarayda doğum olmadığ1 zaman, hanedan üyeleri endişe içine girer, soyun devam etmesi için ellerinden geleni yaparlardı. Yıllar sonra gerçekleşen veladetler, büyük şenlik ve eğlencelerle kutlanırdı. Ancak her padişah çocuğunun veladetinin aynı sevinçle, aynı teşrifat kuralları çerçevesinde kutlandığını söyleyemeyiz. Bunda o dönemin mevcut koşulları, insanların istekleri, şehzade ve sultanların sayısının da etkili olduğunu söyleyebiliriz. Velâdet-i hümâyun hakkında bilgi verdikten sonra bu makalenin asıl konusunu oluşturan XIX. yüzyıl padişahlarından Sultan Abdülaziz'in veladeti hakkında bilgi verilecektir.

\section{Sultan Abdülaziz'in Doğumu}

Sultan Abdülaziz 9 Şubat 1830 (15 Şaban 1245) tarihinde Pazartesi günü, saat 6 sıralarında ve berat gecesinde Eyüp civarındaki Beyhan Sultan Sarayı'nda dünyaya gelmiştir ${ }^{30}$. Babası II. Mahmud ${ }^{31}$ (18081839), annesi Pertevniyal Valide Sultan'd $1 r^{32}$.

Abdülaziz'in doğum haberi ilk olarak baltacılar kethüdası vasıtasıyla Bâbıâli’ye bildirilmiştir. Daha sonra sadaret karakulağı saraya gönderilerek Darüssaade Ağası'nın Bâbıâli'ye geleceği vakit tahkik ettirilmiştir. Askerler, mızıka takımı, kavaslar Bâbıâlinin dış kapısına doğru saf halinde dizilmiş, Kaymakam Paşa ise Divanhane'ye çıkacak kapının iç tarafına konulan bir iskemle üzerinde oturmuş vaziyette Darüssaade Ağası'nı karşılamak için beklemişlerdir. Kaymakam Paşa'nın sağında teşrifat kesedarı ve solunda bölükbaşı ağa bulunmaktadır. Darüssaade Ağası geldiğinde törenle karşılanmış ve Kaymakam Paşa yanına giderek onun elinden hatt-1 hümayunu öperek teslim almış ve sonra reisülküttaba vermiştir. Daha sonra arz odasına geçilmiş ve Kaymakam Paşa mührü açarak hatt-1 hümayunu okumuştur. Duacı çavuşun duasından sonra Arz odasında Darüssaade Ağası ve Kaymakam Paşa oturmuş, dizlerine beyaz şallar konmuş, tatlllar, kahve ve çubuk (tütün) servis edilmiştir. Ertesi gün rikâb resmine kimlerin

25 Râşid Mehmed Efendi Çelebizâde İsmail Âsım Efendi, Târîh-i Râş̧id ve Zeyli (1071-1141/1660-1729), haz. Abdülkadir Özcan vd., I, (İstanbul: Klasik yay., 2013), 49. Bazı kaynaklar şehzadelerin doğumu hakkında ayrıntılı bilgiler verirken bazı kaynaklar sadece doğum tarihini vermekle yetinmişlerdir (IV. Mehmed'in şehzadeleri Mustafa ve Ahmed'in doğumu hakkında bk. Defterdar Sarı Mehmed Paşa, Zübde-i Vekayiât Tahlil ve Metin (1066-1116/1656-1704), haz. Adbülkadir Özcan, (Ankar: TTK, 1995), 255.)

26 Râşid Mehmed Efendi Çelebizâde İsmail Âsım Efendi, a.g.e., 177.

27 Râşid Mehmed Efendi Çelebizâde İsmail Âsım Efendi, a.g.e., 433; Defterdar Sarı Mehmed Paşa, a.g.e., 437.

28 Ayrıntılı bilgi için bk. Mehmet Arslan, Osmanlı Saray Düğünleri ve Şenlikleri "Haşmet Sûrnâmesi", 6-7, (İstanbul: Çamlıca yay., 2011).

29 Kemal Beydilli, "Mustafa III", TDV İslâm Ansiklopedisi, XXXI (İstanbul 2006), 282. Ayrıca bk. Kemal Beydilli, "III. Mustafa (17571774). Kaynarca Öncesi Bir Padişah Portresi", Ottoman Studies, band 8, (Almanya :2019), 189-245.

30 TSMA, E. 690/4; TSMA, D. 5252/4; AE. SMHD.II, 8/41; BOA, Sadaret Defterleri (A.d.), 363, s. 4.

31 TSMA, E. 597/14.

32 Bk. Ali Akyıldız, "Müsrif, Fakat Hayırsever: Pertevniyal Valide Sultan”, Osmanlı Araştırmaları, XLVII (2016): 345-346; Ali Akyıldı,, "Pertevniyal Vâlide Sultan", TDV İslâm Ansiklopedisi, XXXIV (İstanbul 2007), s. 239-240. 
geleceğini bildiren sadrazamın telhisi reisülküttap tarafından bir yastık üzerinde darüssaade ağasına verilmiş ayrıca yakası sırmalı harvani ve dülbende sarılı şekilde muhafaza edilmiş mücevher kutu, teşrifati efendi tarafından yine Darüssade Ağası'na sunulmuştur. Bundan sonra şerbet, gülsuyu ve buhur merasimi yapılmıştır. Telhis ve verilen hediyeler Darüssaade yazıcısına verilmiş ve saraya gitmek üzere harekete geçen Darüssaade Ağası'na uğurlama merasimi yapılmıştır. Bu merasim süresince Darüssaade Ağası'na 12.000, orada görevli hademelere 500, duacı çavuşa 100, kara kulağa 500 kuruş olmak üzere toplamda 17.000 kuruş masraf edilmiştir. ${ }^{33}$

Sultan Abdülaziz dünyaya geldiğinde doğum haberi Hazine vekili Abdullah Ağa vasitasıyla II. Mahmud'a bildirilmiş, tekrar şehzade babası olduğundan dolayı çok mesut olan padişah bu şehzadeye “Abdülaziz” ismini vermiştir. Şehzade doğumunu Darüssaade Ağası Bâbıâli’ye, Silahtar Ağa seraskerliğe giderek müjdelemiş ve ertesi günün sabahında şeyhülislam, kaymakam ve serasker saraya giderek padişaha tebriklerini iletmişlerdir. Doğumdan sonra Enderun-1 humâyun ağalarına altın ihsan edilmiştir ${ }^{34}$. Sultan Abdülaziz'in doğumu bir hatt-1 hümâyunla sadrazama bildirilmiş ${ }^{35}$, sadrazam Reşid Mehmed Paşa (1829$1833)^{36}$ ise velâdet sebebiyle II. Mahmud'u tebrik için bir arîza kaleme almıştır ${ }^{37}$.

Sultan Abdülaziz' in velâdeti şehrin her tarafinda yedi gün boyunca üçer nöbet toplar atılmak suretiyle halka duyurulmuştur ${ }^{38}$. Şehzade doğumunu haber alan halk da bu haberi sevinçle karşılayarak doğum münasebetiyle yapılan şenliklerde gönüllerince eğlenmiştir. Doğumdan sonra şehirde yedi gün yedi gece fişek donanması tertip edilmiş ve bu donanmanın yanı sıra sarayda her gün rakkaseler eşliğinde çeng ve rebab çalınarak müzik gösterileri sahnelenmiştir ${ }^{39}$.

Sultan Abdülaziz'in doğumu Osmanlı Devleti'nin çeşitli eyaletlerine de ferman gönderilerek haber verilmiş ve şehzadenin velâdeti mahkemelere kayıt edilerek tüm Osmanlı toprakları genelinde de top atış1 ve şenliklerle kutlanmıştır. Mesela Sakız Adası'nda veladet tarihi mahkemede kaydedilmiş ve adada velâdet dolayısıyla yedi gün boyunca top ve tüfek şenlikleri düzenlenmiştir. ${ }^{40}$ Yine Drama' da, Gümülcine ve Alasonya'da şehzade Abdülaziz'in veladeti kadılar tarafından kayıt edilerek top ve tüfek şenliğiyle kutlanmıştır. ${ }^{41}$

Hızır İlyas eserinde Sultan Abdülaziz’in velâdetini şu sözlerle aktarmaktadır:

"İ̧̧bu şeh-ri Şâban-ı şerîfin on beşinci isneyn günü, hâkân-ı a'zam, sultan-ı muazzam efendimizin mübârek sulb-ı pâklerinden yine bir şehzâde-i servâzâdeleri zîb-i arâyiş-i gehvâre-i vücûd ve nakş-l zibâyiş-i evreng-i şühûd oldukları haber-i meserret-eseri, hazine vekili Paşaçırağı Abdullah Ă̆a vâsıtasıyla sem '-i şâhâneye vâsıl ve o anda derecesiz safâ-yı ruhânî hâsıl olup, hemen ism-i sâmileri Sultan

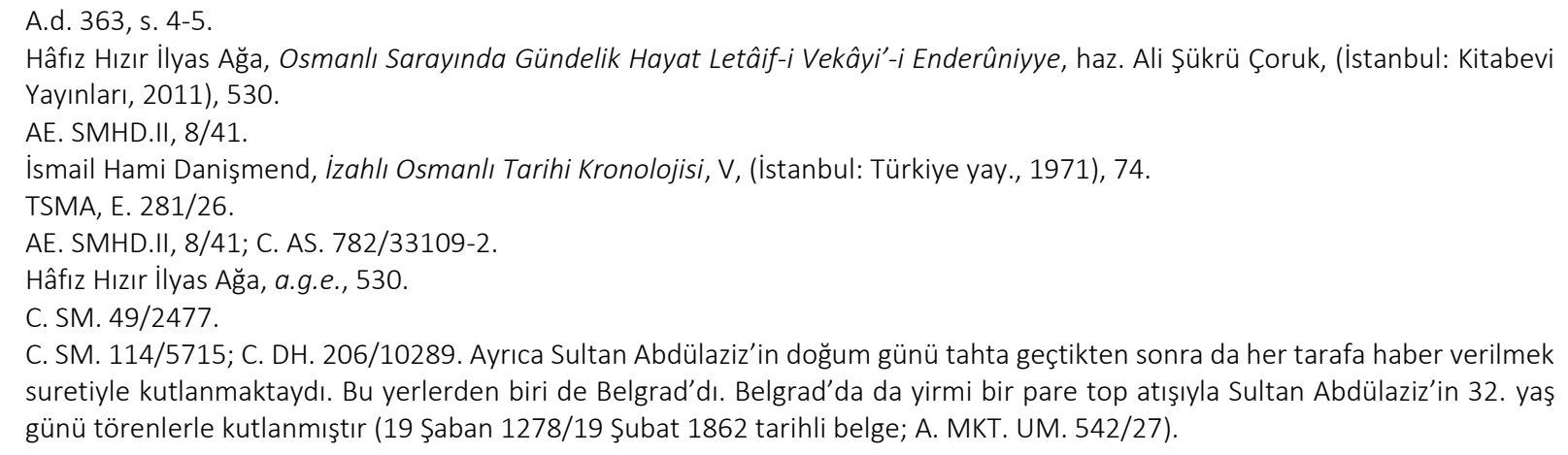


Abdülaziz tesmiye buyrulduğu ilân ve kâide-i kadîme-i devlet-i fahîme üzere yedi gün ve yedi gece fişek donanması olmasına ruhsat-ı şâhâne erzân buyrulmakla..." 42

Hafız Hızır İlyas eserinde şehzadenin doğumundan ve bütün bu eğlence ve ihsanlardan duyduğu sevinci dile getirmenin zor olduğunu fakat acizane şükür ve teşekkürünü göstermek için bir kıta dua kaleme aldığını ifade eder:

Bir velî-nimetim vardır benim kim Nevresâ

Gördüğ̈̈m in 'âmını ihsânını etsem hesâb

Nüsha-i ta'dâd-ı a'dâdında olup intihâ

Evvel dibâcede lâzım gelir temme 'l-kitâb ${ }^{43}$

Yukarıda şehzade doğumlarında tarih düşürüldüğünü ifade etmiştik. Hızır İlyas, Sultan Abdülaziz'in doğumuna da birçok tarih düşürüldüğünü fakat bunlardan sadece ikisinin kendisinde mevcut olduğundan bahseder. Bunlardan biri hazine odasından Ekmel Bey'in;

Nazm u nesre oldu dest-res nev-heves Ekmel yine

Alemi hep kıldı şen şehzâdemiz Abdülazîz

Çantacı Nazif Efendi'nin ise;

"Şevk ü şâdiyle Nazîfâ söyledim târîh-i tâm

Âlemi etdi azîz şehzâdemiz Abdülazîz" düşürdükleri tarihlerdir ${ }^{44}$.

Osmanlı Devleti'nin vakanüvislerinden olan Ahmed Lütfi eserinde Sultan Abdülaziz'in 9 Şubat 1830 tarihinde berat gecesinde Eyyüb-i Ensâri civarındaki II. Mahmud'un kız kardeşi Esma Sultan Sarayı'nda ${ }^{45}$ dünyaya geldiğini ifade etmiş ve doğumuna bir tarih düşürmüştür:

Cevher-i tarihi tenvir etdi mehd-i devleti

Nûr-ı hak Abdülaziz Sultan doğdu müjde-bâd ${ }^{46}$

Osmanlı hanedanına yeniden bir şehzade dünyaya getiren Pertevniyal Valide Sultan'ın haremde kendisine tahsis edilen odasına şehzade doğumundan ötürü yeni eşyalar ve mücevherler getirilmiştir ${ }^{47}$. Bu hediyeler arasında; "mücevher arasında pirlanta elmas ile müzeyyen maşallah, pırlanta elmasl horos mahmuzu, sim kaplama bağa” gibi eşyaların bebeğin nazardan korunması için kullanıldı̆̆ını söyleyebiliriz. Ayrıca yeni doğan şehzade için odaya; “ceviz beşik ve kundak yorganı” teslim edilmiştir.

Odanın yeniden dekorasyonu için ise; "pırlanta elmas ile müzeyyen mücerred zümrüd âvîze, pırlanta elmas ile müzeyyen kırmızı yakut avize, pırlanta elmas ile müzeyyen pîrûze avize" hareme teslim edilen nadide eşyalardandır. Odanın genel ihtiyaçları için; "yaldızlı nuhas leğen, yaldızlı nuhas tas, yaldızlı nuhas abdest leğeni, penbeli dülbend yorgan şiltesi, dülbend yorgan çarşab, dülbend minder şiltesi" verilmiştir.

42 Hâfız Hızır ilyas Ağa, a.g.e., s. 530.

43 Hâfız Hızır ilyas Ağa, a.g.e., s. 530.

44 Hâfız Hızır ilyas Ağa, a.g.e., s. 531.

45 Eyüp'te Bahariye sahilinde Bostan iskelesinin yanında sırayla Beyhan, Hadice ve Esma Sultan'a ait yalılar bulunmaktaydı. Dolayısıyla Lütfi Efendi'nin yalıları karıştırmış olması ihtimal dahilindedir (bk. Türkan Duran, “I. Abdülhamid'in Kızı Esma Sultan’ın Hayatı (1778-1848)", (Yüksek Lisans Tezi, Marmara Üniversitesi, 2007), 50.

46 Ahmet Lütfî Efendi, Târih-i Lütfî, II, (İstanbul: Matbaa-i Amire, 1291), 174.

47 TSMA, D. 239/1. 
Şehzadenin annesi için verildiğini tahmin ettiğimiz; "kırmızı yakut yüzük, pîrûze/firuze, şeşhane zümrüd" ise mücevherler arasındadır. Ayrıca Sultan Abdülaziz'in validesine elbise bedeli olmak üzere 7.500 kuruş ihsan edilmiştir ${ }^{48}$. Odada bulunanların kullanması için ayrıca şu eşyalar da verilmiştir: "şal takye, dülbend takye, penbeli kuşlık dülbend entari, penbeli klşlık dülbend içlik, penbeli dülbend etek bezi, penbeli dülbend kol bezi, penbeli dülbend ayak bezi, penbeli dülbend yorgan şiltesi, düz şal parçası, hindî düz dülbend, kışlık dülbend, al atlas, kılabdanlı nimten”. Doğum müjdesi olarak hareme teslim edilen bu eşyalara baktığımızda XIX. yüzyılda Osmanlı sarayında doğum sonrası yapılan geleneklerden ve bu dönemin maddi kültürünü anlayabilmemiz açısından önemlidir.

Şehzade doğumundan sonra sadece valideye değil saray görevlilerine de ihsanlar veriliyordu. Abdülaziz'in doğumundan sonra da saraydaki görevlilere ihsanlar verildiğini kaynaklardan öğrenebiliyoruz ${ }^{49}$. Sultan Abdülaziz'in veladetinin birinci günü validesi başta olmak üzere, hazinedar ustaya, ebe kadınlara, silahtar ağaya, babüssaade ağasına, rikabdar ağaya, has odabaşı ağaya, dülbend ağasına, hazine-i hümâyun ağasına, kilar kethüdasına, seferli kethüdasına, miftah ağasına, peşkir ağasına, imam-1 evvel ve sânî efendi dâilerine, Galata ağasına, saray ağasına, saray kethüdasına, katib-i evvel ve miftah ve serhüddam-1 hazine kullarına, şerbetçi ağaya, sırkatibi efendinin yamağına, çantacıya, ikinci kullukçuya, Hane-i hassa ağalarına, Darüssaade ağalarına, Babüssaade ağalarına, hazine-i hümâyun ağalarına, kilar-1 hassa ağalarına, hane-i seferli ağalarına, Râmi mevkib-i hümâyunda süvari ve mızıkacı ağalara, Galata Saray’da mevcud ağalara, teberdaran-1 hassa kullarına ihsanlar verilmiştir.

Sultan Abdülaziz'in veladetinin ikinci ve üçüncü günü padişah II. Mahmud'un Râmi mevkiinde olduğunu görmekteyiz. Padişah bu civarda iken doğum müjdesi olarak Silahdar Ağa'ya, sırkatibi Efendi'ye, Baş Ağa'ya, Mustafa Ağa'ya, Hazine-i hümâyun kethüdasına, Mabeyn-i hümâyun hademelerine, kahveci, şerbetçi ağaları ve güğümcü ağalara, Dülbend ağaya, tablakarlara, Topkapı, Beşiktaş, Çırağan ve Şemsi Paşa bekçilerine, mabeyn kapıcısına, dolabçılara, bahçıvan ve suyolculara, Râmi Çiftliği kışlağındaki kapıcılara, iskemlecibaşına, Gülhane kasr-1 hümâyunu bekçisi ve neferâtına, kozbekçi ve teberdaran-1 atik neferâtına, helvacılara, on adet kayıkçılara, saray hademelerine, tebdil uşaklarına, Râmi Çiftliği kışlağında kapıcılara, sancakdarlar ve diğer bazı görevlilere ihsan verilmiştir. Yine bu ihsanların miktarı değişiklik göstermektedir.

Sultan Abdülaziz'in veladet kutlamalarının son gününde ise baş musahib ağa ve diğer musahib ağalara, baş çavuş ağa ve diğer çavuş ağalara, enderun mehter ağalarına, birun mehterleri, hayalbazan, meddahan, çengiyan, köçekler, perdebazan, hokkabazan, kuklabazan ve kıptiyan çalgıcılarına ihsan verilmiştir.

Sultan Abdülaziz'in velâdetinde yukarıda değindiğimiz tüm bu kişilere ihsan olarak verilmesi için Darphane-i Âmire'den 112.920,5 kuruş para çıkarılması hazine kayıtlarında yer almıştır ${ }^{50}$.

Bu verilere baktığımızda XIX. yüzyılda bir veladet gerçekleştiğinde kimlere ne kadar ihsan verildiği, o dönemde hangi saray görevlilerinin bulunduğu, veladet kutlamalarının kaç gün sürdüğü hakkında bilgi edinebiliriz. En sonda ek olarak vereceğimiz tabloda görüleceği üzere ihsanların miktarı görevlilerin kıdemine göre değişmektedir. Mesela Enderun içerisinde bulunan koğuşlardan has odalı 34 nefer ağanın her birine 40 kuruş ihsan verilirken, hazine, kiler ve seferli odasında bulunan ağalara onar kuruş, teberdaran1 hassaya ise beşer kuruş ihsan verilmiş̦tir. Ayrıca veladetin son gününde ihsanların verildiği kişiler ve veladet kutlamalarında ne tür eğlenceler tertip edildiği hakkında fikir edinebiliriz. Şöyle ki veladet

\footnotetext{
TSMA, D. 239/1.

9 TSMA, D. 2476/8.

50 TSMA, D. 2476/8.
} 
sonrasında sarayda veya saray dışında hayalcilerin, meddahların, kuklacıların, hokkabazların çeşitli marifetlerini sergilediğini, müzikler eşliğinde köçeklerin ve çengilerin dans ettiğini, Enderun ve Birun mehterlerinin de veladet kutlamalarına iştirak ettiğini söyleyebiliriz.

Sultan Abdülaziz'in doğumu ile birlikte saray teşrifatı ve teşkilatında birtakım değişikliklere gidilmiştir. II. Mahmud, şehzade veya sultanların doğumu münasebetiyle gerçekleştirilen törenler ve verilen hediyelerin padişah ve devlet görevlilerini maddi açıdan zor duruma sokmasından dolayı hediye ve bahşişlerin azaltılmasını içeren yeni teşrifat kuralları ortaya koymuş ve bu kurallara uyulması konusunda sadrazamı uyarmıştır. Mesela daha önceden padişah çocuğu dünyaya geldiği vakit doğumu sadrazama müjdeleyen Darüssaade ağasına elli kese (25.000 kuruş), 10.000 kuruş değerinde mücevher, kürk, donanmış at verilirken Sultan Abdülaziz'in doğumunda Darüssaade ağasına verilen hediyeler 17.000 kuruş kadardır. Aynı zamanda sadrazam ve sadaret kethüdası tarafından padişaha verilen donanmış at verme zorunluluğu ortadan kaldırılmıştır. Doğumun üçüncü günü İstanbul'daki selatin camilerinde bulunan şeyhlere kahve ikramı ve para ihsanında bulunulmuştur. ${ }^{51}$ Teşrifattaki bu değişiklik nedeniyle Sultan Abdülaziz' in doğumunda yapılan harcamaların önceki dönemlere göre düşük olduğu görülmektedir.

$\mathrm{Bu}$ anlatılanlar haricinde Abdülaziz'in doğumundan hatıra bir arşiv bulgusu tespit edilmiştir. Osmanlı Arşivi'nde Mabeyn-i Hümâyun evrakları arasında yer alan bu belgenin üst ve alt tarafında küçük bir el izi bulunmakta ve belgenin sol orta kısmına şu açıklama yazılmıştır: "Necâbetlü Sultan Abdülaziz hazretleri dünyaya kadem basdıkları vakitde kendi mübarek yed-i şeriflerinin basdiğı nişan ve resm-i bergüzar olmak himmetinde tahrire ibtidar olundu. "52. Bu iki küçük el izinin Sultan Abdülaziz'e ait olduğu aşikardır. Kuvvetle muhtemel şehzade Abdülaziz doğduğunda saray mâiyyeti arasında sevinçle karşılanmış, geleneksel törenler düzenlenmiştir. Şüphesiz bu doğuma en fazla sevinenlerin başında padişah yani II. Mahmud ve bebeğin annesi Pertevniyal Valide Sultan gelmektedir. Sultan Abdülaziz doğduktan sonra elleri mürekkebe batırılarak sağ eli belgenin alt kısmına, sol eli ise belgenin üst kısmına bastırılması suretiyle bebek Abdülaziz'in el izi çıkarılmış olmalıdır. Belgedeki açıklamaya göre böyle bir faaliyette bulunulmasının nedeni şehzadenin doğumu dolayısıyla bir hatıra bırakmaktı. Düşündükleri gibi de oldu; Sultan Abdülaziz'in el izi günümüze bir hatıra olarak kaldı. Ancak Sultan Abdülaziz'in elleri ileride tartışmalara sebebiyet veren önemli bir hadiseye de kapı açacaktır.

Bilindiği üzere Sultan Abdülaziz iki elinin bileklerinden kesilmek suretiyle ölü vaziyette bulunmuştur $^{53}$. Bu hadise intihar ${ }^{54}$ olarak kamuoyuna duyurulmuşsa da II. Abdülhamid döneminde yapılan mahkeme kararında Sultan Abdülaziz'in intihar etmediği, katledilerek öldürüldüğü açıklanmıştır. Failler mahkemede yargılanıp idam cezası verilmesine rağmen II. Abdülhamid bu cezayı müebbet kürek cezasına çevirmiştir $^{55}$. Daha sonraki tarihçilerden Abdurrahman Şeref ve İbnülemin Mahmut Kemal İnal, Abdülaziz'in katledildiğine dair kesin bir şey söylemekten imtinâ etmişlerdir ${ }^{56}$. Osmanlı Devleti’nde

51 Ali Akyıldız, "Modern Bir Geleneğin Tarihteki İzdüşümü: Bebek (Sultan) Abdülaziz'in Elinin İzleri”, Toplumsal Tarih 324 (Aralık 2020): 64; A.d., 363, s. 5.

52 Mabeyn-i Hümayun Evrakı (MB), 939/60. (Ali Akyıldız bu notun Pertevniyal Valide Sultan'ın el yazısı olduğunu ifade etmektedir bk. Ali Akyıldız, a.g.m., 66).

53 Vefat tarihi: 12 Cumâdelevvel 1293/5 Haziran 1876 Pazar (Y. PRK. SGE. 1/2; TSMA, E. 860/31).

54 Sultan Abdülaziz'in cesedini inceleyen ve intihar ettiğine hükmeden 19 doktorun isminin bulunduğu rapor hakkında bk. HR. TO. $516 / 54$.

55 Cevdet Küçük, “Abdülaziz", DiA, I (İstanbul 1988), 184-185.

56 Turgut Subaşı, "Sultan Abdülmecid ve Sultan Abdülaziz", Türkler, XII (Ankara 2002), s. 778. Ayrıca Sultan Abdülaziz'in ölüm hadisesi için bk. Mustafa Göleç, “II. Abdülhamid ve II. Meşrutiyet Devri Tarih Ders Kitapları ile ilgili Monografilerde Abdülaziz'in Katli Yahut Intiharı Meselesi", Sultan Abdülaziz ve Dönemi Sempozyumu 12-13 Aralık 2013, Ankara Ordu ve Siyaset Bildiriler, 
hanedan ve hanedan üyelerinin kanını akıtmak geleneğe aykırıydı bu yüzden hanedan üyeleri boğdurulmak suretiyle öldürülmüşlerdir. Sultan Abdülaziz'in katledildiği varsayımına bakacak olursak sabık padişahın failleri gerçeğin gün yüzüne çıkmaması için padişahı önce boğup sonra bileklerinden makasla kesmiş olabilir. Eğer tam tersine intihar ettiği varsayımı kabul edilirse bir makasla bir bileğin kesilip, kesilmiş bir bilekle diğer bileğin kesilmesinin tıbben mümkün olamayacağı tahmin edilebilir.

Kim tarafından yazıldığı belli olmayan imzasız bir belgedeki ifadeye göre Sultan Abdülaziz vefat ettiğinde üzerinde bulunan kanlı elbisenin konulduğu boğça üzerinde şunlar yazılmıştır:

"Cennemekân firdevs-i âşiyan Sultan Abdülaziz Han ibn Sultan Mahmud Han-ı sâni hazretlerinin 1293 senesi Cemaziyelevvelin yedinci salı günü Beşiktaş Sahilsarayı hümâyununda iken sabahleyin saat on ikide hal' edilip yevm-i mezkurde sabahleyin Yeni Saray harem-i hümâyununa getürülüb saray-ı hümâyunu mezkûrda üç gece yattukdan sonra Ortaköy civarında vâkl' müceddeden inşa olunan Feriye sahil sarayına nakl ettirilüb ikinci pazar günü sabahleyin saat üçte kendüsi iki kollarının kan damarlarını mıkraz kat 'eyleyerek irtihal darü'l-bekâ etmişs hal olunduğu fi Ca 7 sene 283 yevm-i salı" ${ }^{\text {"57. }}$.

Sultan Abdülaziz'in oğlu Yusuf İzzeddin Efendi'nin de aynı akıbete uğraması şaşırtıcıdır. Yusuf İzzeddin Efendi yatağında sol kol damarı kesilmiş vaziyette ölü olarak bulunmuştur. Kimilerine göre kanser hastalığından dolayı ruhen sıkıntılı bir evre geçirdiğinden dolayı intihar ettiği, kimilerine göre devletin kötü durumuna üzüldüğü için intihara kalkıştığı, bazılarına göre ise ittihatçılar tarafindan öldürüldüğü söylenmektedir ${ }^{58}$. Baba ve oğulun şüpheli akıbetleri hâlen tartışılmaktadır.

(2014): 33-63; Ahmet Özcan, "Sultan Abdülaziz Öldürüldü mü, İntihar mı Etti?”, Sultan Abdülaziz ve Dönemi Sempozyumu 1213 Aralık 2013, Ankara Ordu ve Siyaset Bildiriler, (2014): 1-13.

57 TSMA, E. 860/31.

58 Ayrıntılı bilgi için bk. Hasan Ünlü, "Veliahd Yusuf İzzeddin Efendi (1857-1916)” (Yüksek Lisans Tezi, Mimar Sinan Güzel Sanatlar Üniversitesi, 2019.) 


\section{Sonuç}

Osmanlı Devleti'nde teşrifat kurallarına riayet etmek son derece mühimdi. Sarayda, daha önce belirlenen kaidelere göre bir düzen oluşturuluyor ve uygulanıyordu. Padişah çocuklarının doğumu da daha önceden belirlenen teşrifat kuralları çerçevesinde kutlanır, merasim düzeni bu kurallara göre oluşturulurdu.

Sultan Abdülaziz'in doğumundan itibaren teşrifatta bir takım değişmeler meydana gelmiştir. II. Mahmud oğlu Abdülaziz'in doğumu ile birlikte doğum dolayısıyla yapılacak olan harcamaların azaltılmasını istemiş ve teşrifat kuralları da bu doğrultuda değiştirilmiştir. Sultan Abdülaziz'in doğumunda dikkat çeken hususlardan biri de doğumundan sonra alınan el izidir. Osmanlı kaynaklarında böyle bir teamülün varlığından söz edilmediği gibi arşiv kaynaklarında da benzeri bir örneğine rastlanmamıştır. Bebeklerin el izinin alınmasının geçmişte ve günümüzde gelenek haline dönüşmediğini ancak bu belge vasıtasıyla 1830 tarihinde saray içerisinde böyle bir uygulamanın gerçekleşmiş olduğunu söylemek mümkündür.

Neticede doğumunun büyük sevinçlere yol açtığı, devlete çeşitli hizmetlerde bulunmuş bir hükümdarın Sultan Abdülaziz'in kişiliği, yaşamı, icraatları, hal edilmesi, ölüm hadisesi tartışılmaya devam edecektir. Bu makalede sadece Sultan Abdülaziz'in veladetinin detaylarını içeren bir panorama çizilmiştir. 


\section{Kaynakça}

\section{Arşiv Kaynakları}

Başbakanlık Osmanlı Arşivi (BOA), Ali Emiri Mahmud II (AE. SMHD.II), 8/41.

BOA, Cevdet Askeriye (C. AS.), 782/33109.

BOA, Cevdet Dahiliye (C. DH.), 206/10289.

BOA, Cevdet Saray (C. SM.), 49/2477.

BOA, C. SM. 114/5715.

BOA, Hariciye Nezareti Tercüme Odas1 (HR. TO.), 516/54.

BOA, Mabeyn-i Hümayun Evrakı (MB), 939/60.

BOA, Mektubi Kalemi Evrakı Umum Vilayat Evrakı (A. MKT. UM.), 542/27.

BOA, Plan-Proje-Kroki Plan-Projeler (PLK, p.) 1076/1.

BOA, Sadaret Defterleri (A.d.), 363, s. 4.

BOA, Topkapı Sarayı Müzesi Arşivi Defter (TSMA, D.), 66/1.

BOA, TSMA, D. 118/1.

BOA, TSMA, D. 5252/4.

BOA, TSMA, D. 239/1.

BOA, TSMA, D. 2476/8.

BOA, Topkapı Sarayı Müzesi Arşivi Evrak (TSMA, E.), 125/51.

BOA, TSMA, E. 690/4.

BOA, TSMA, E. 597/14.

BOA, TSMA, E. 281/26.

BOA, TSMA, E. 860/31.

BOA, Yıldız Mabeyn Erkanı ve Saray Görevlileri Maruzatı (Y. PRK. SGE.), 1/2.

\section{Kaynak Eserler ve İncelemeler}

Acar, Funda, “Osmanlıda Padişah Oğulları ve Kızlarının Eşitlendiği Alan: Teşrifat”, Hitit Üniversitesi Illahiyat Fakültesi Dergisi 14/XXVII (2015): 183-202.

Ahmed Cevdet Paşa, Târîh-i Cevdet, haz. Şevki Nezihi Aykut, II. Cilt-I. Kitap, Ankara: TTK, 2018.

Ahmet Lütfî Efendi, Târih-i Lütfí, II, İstanbul: Matbaa-i Amire, 1291.

Akyıldız, Ali, "Müsrif, Fakat Hayırsever: Pertevniyal Valide Sultan", Osmanlı Araştırmaları, XLVII (2016): 307-352.

Aky1ldız, Ali, "Pertevniyal Vâlide Sultan”, TDV İslâm Ansiklopedisi XXXIV (İstanbul 2007), ss. 239-240.

Akyıldız, Ali, “Modern Bir Geleneğin Tarihteki İzdüşümü: Bebek (Sultan) Abdülaziz’in Elinin İzleri”, Toplumsal Tarih, 324 (Aralık 2020): 62-67.

Ali Seydi Bey, Teşrifat ve Teşkilatımız, İstanbul: Tercüman yay., tarihsiz.

Alikılıç, Dündar, Osman'da Devlet Protokolü Ve Törenler Imparatorluk Seremonisi, İstanbul: Tarih Düşünce Kitapları yay., 2004. 
Arslan, Mehmet, Osmanlı Saray Düğünleri ve Şenlikleri “Haşmet Sûrnâmesi”, 6-7, İstanbul: Çamlıca yay., 2011.

Beydilli, Kemal, “Mustafa III”, TDV İslâm Ansiklopedisi XXXI (İstanbul 2006), ss. 280-283.

Beydilli, Kemal, “III. Mustafa (1757-1774). Kaynarca Öncesi Bir Padişah Portresi”, Ottoman Studies, band 8 (2019): 189-245.

Danişmend, İsmail Hami, İzahlı Osmanlı Tarihi Kronolojisi, V, İstanbul: Türkiye yay., 1971.

Defterdar Sarı Mehmed Paşa, Zübde-i Vekayiât Tahlil ve Metin (1066-1116/1656-1704), haz. Adbülkadir Özcan, Ankara: TTK, 1995.

Duran, Türkan, “I. Abdülhamid'in Kızı Esma Sultan'ın Hayatı (1778-1848)”, Yüksek Lisans Tezi, Marmara Üniversitesi, 2007.

Eroğlu, Haldun, "Şehzade”, TDV İslâm Ansiklopedisi XXXVIII (İstanbul 2010), ss. 480-483.

Göleç, Mustafa, "II. Abdülhamid ve II. Meşrutiyet Devri Tarih Ders Kitapları ile İlgili Monografilerde Abdülaziz'in Katli Yahut İntiharı Meselesi”, Sultan Abdülaziz ve Dönemi Sempozyumu 12-13 Aralık 2013, Ankara Ordu ve Siyaset Bildiriler, (2014): 33-63.

Hâfız Hızır İlyas Ağa, Osmanlı Sarayında Gündelik Hayat Letâif-i Vekâyi'-i Enderûniyye, haz. Ali Şükrü Çoruk, İstanbul: Kitabevi Yayınları, 2011.

Küçük, Cevdet, “Abdülaziz”, TDV İslâm Ansiklopedisi I (İstanbul 1988), ss. 179-185.

Nâîmâ Mustafa Efendi, Târih-i Na îmâ (Ravzatü'l-Hüseyn Fî Hulâsati Ahbâri’l-Hâfikayn), haz. Mehmet İpşirli, I-II-III-IV, Ankara: TTK, 2007.

Râşid Mehmed Efendi Çelebizâde İsmail Âsım Efendi, Târîh-i Râşid ve Zeyli (1071-1141/1660-1729), haz. Abdülkadir Özcan vd., c. I-II-III, İstanbul: Klasik yay., 2013.

Özcan, Ahmet, "Sultan Abdülaziz Öldürüldü mü, İntihar mı Etti?", Sultan Abdülaziz ve Dönemi Sempozyumu 12-13 Aralı 2013, Ankara Ordu ve Siyaset Bildiriler, TTK yay, Ankara 2014, 1-13.

Subaş1, Turgut, "Sultan Abdülmecid ve Sultan Abdülaziz", Türkler, XII (Ankara 2002), ss. 753-781.

Tarım, Zeynep, “Osmanlı İstanbul'unda Merasim ve Teşrifata Dair Kaynaklar”, Türkiye Araştırmaları Literatür Dergisi 8/XVI (2010): 131-148.

Tarım, Zeynep, “Osmanlı Devleti’nde Resmî Törenler ve Birkaç Örnek”, Osmanlı, IX (Ankara 1999), ss. 133-142.

Tayyâr-zâde Atâ, Osmanlı Saray Tarihi-Târîh-i Enderûn, haz. Mehmet Arslan, I-V, İstanbul: Kitabevi Yayınları, 2010.

Uluçay, Çağatay, Harem, İstanbul: Ötüken yay., 2011.

Uluçay, Çağatay, Padişahın Kadınları ve Kızları, Ankara: TTK, 2001.

Uzunçarşıl1, İsmail Hakkı, Osmanlı Devletinin Saray Teşkilâtı, Ankara: TTK, 1988.

Ünlü, Hasan, "Veliahd Yusuf İzzeddin Efendi (1857-1916)”, (Yüksek Lisans Tezi, Mimar Sinan Güzel Sanatlar Üniversitesi, İstanbul 2019). 


\begin{tabular}{|c|c|c|c|}
\hline \multicolumn{4}{|c|}{ Sultan Abdülaziz’in Velâdet-i Hümâyunu'nun Birinci Gününde Verilen İhsanlar ${ }^{59}$} \\
\hline Kime Verildiği & Nefer Sayısı & $\begin{array}{l}\text { Bir günlük ihsan } \\
\text { (kuruş) }\end{array}$ & $\begin{array}{l}\text { Bir aylık ihsan } \\
\text { (kuruş) }\end{array}$ \\
\hline Vâlide-i muhteremleri hazretlerine & & 15.000 & \\
\hline Hazînedar usta câriyelerine & & 25.000 & \\
\hline Ebe kadın câriyelerine & & 2.500 & \\
\hline $\begin{array}{l}\text { İhsan? olarak harem-i muhtereme teslim } \\
\text { olunan }\end{array}$ & & 2.500 & \\
\hline Silâhdar-1 hazret-i cihandârî ağa kullarına & & 220 & \\
\hline Babüssaâde ağası ağa kullarına & & 100 & \\
\hline Rikâbdar ağa kullarına & & 80 & \\
\hline Hasodabaşı ağa kullarına & & 80 & \\
\hline Dülbend ağasına & & 60 & \\
\hline Hazine-i hümâyun ağası kethüdasına & & 220 & \\
\hline Kilâr kethüdâsina & & 100 & \\
\hline Seferli kethüdâsına & & 100 & \\
\hline Miftah ağasına & & 60 & \\
\hline Peşkir ağasına & & 60 & \\
\hline İmam-1 evvel ve sânî efendi dâilerine & & 160 & \\
\hline Galata ağası ağa kullarına & & 40 & \\
\hline Saray ağası kullarına & & 30 & \\
\hline Saray kethüdâsı kullarına & & 30 & \\
\hline $\begin{array}{l}\text { Katib-i evvel ve miftah ve serhüddam-1 } \\
\text { hazîne kullarına }\end{array}$ & & 180 & \\
\hline Şerbetçi ağa kullarına & & 20 & \\
\hline Sırkâtibi efendinin yamağı kullarına & & 20 & \\
\hline Çantacı kullarına & & 40 & \\
\hline İkinci kullukçu kullarına & & 20 & \\
\hline Hane-i hassa ağaları kullarına & 34 & $\begin{array}{r}1.360 \\
\text { (40 kuruştan) }\end{array}$ & 4080 \\
\hline Darüssaâde ağaları kullarına & & 1.000 & 3000 \\
\hline Babüssaâde ağaları kullarına & 31 & $\begin{array}{r}310 \\
\text { (10'ar kuruştan) }\end{array}$ & 930 \\
\hline Hazîne-i hümâyun ağaları kullarına & 43 & $\begin{array}{r}430 \\
(10 \text { 'ar kuruştan) }\end{array}$ & 1290 \\
\hline Kilar-1 hassa ağaları kullarına & 46 & $\begin{array}{r}460 \\
(10 \text { 'ar kuruştan) }\end{array}$ & 1380 \\
\hline Hane-i seferli ağaları kullarına & 44 & $\begin{array}{r}440 \\
(10 \text { 'ar kuruştan) }\end{array}$ & 1320 \\
\hline $\begin{array}{l}\text { Râmi mevkib-i hümâyunda süvari ve } \\
\text { muzıkacıyan ağalar kullarına }\end{array}$ & 304 & $\begin{array}{r}3040 \\
(10 \text { 'ar kuruştan) }\end{array}$ & 9120 \\
\hline $\begin{array}{l}\text { Galata Sarayı hümâyununda mevcud } \\
\text { ağavat kullarına }\end{array}$ & 212 & $\begin{array}{r}1.060 \\
\text { (5'er kuruştan) }\end{array}$ & \\
\hline Teberdaran-1 hassa kullarına & 109 & $\begin{array}{r}545 \\
(5 \text { 'er kuruştan) }\end{array}$ & 1635 \\
\hline
\end{tabular}




\begin{tabular}{|c|c|c|c|}
\hline Sofalılar kullarına & & 500 & \\
\hline \multicolumn{4}{|c|}{ Sultan Abdülaziz’in Velâdetinin İkinci Gününde Râmi Mevkib-i Hümâyununda Verilen İhsanlar } \\
\hline Kime Verildiği & Nefer Sayısı & $\begin{array}{l}\text { Bir günlük ihsan } \\
\text { (kuruş) }\end{array}$ & $\begin{array}{l}\text { Bir aylık ihsan } \\
\text { (kuruş) }\end{array}$ \\
\hline Silâhdar Ăga'ya & & 88 & \\
\hline Sırkâtibi Efendi'ye & & 33 & \\
\hline Baş Ağa kullarına & & 33 & \\
\hline Mustafa Ağa'ya & & 33 & \\
\hline Hazîne-i hümâyun kethüdâsına & & 33 & \\
\hline Mabeyn-i hümâyun hademelerine & & 190 & \\
\hline $\begin{array}{l}\text { Kahveci, şerbetçi ağaları ve güğümcü } \\
\text { ağalara }\end{array}$ & & 70 & \\
\hline $\begin{array}{l}\text { Dülbend ağa ve iki aded kuşçu ve } \\
\text { tablakârlara }\end{array}$ & & 60 & \\
\hline Nân-1 aziz getüren ortak kullarına & & 20 & \\
\hline $\begin{array}{l}\text { Topkapı ve Beşiktaş ve Çırağan ve Şemsi } \\
\text { Paşa bekçiyan kullarına }\end{array}$ & & 105 & \\
\hline Mabeyn kapıcısı kullarına & & 6 & \\
\hline Neferâtı kullarına & & 12 & \\
\hline Dolabcı kullarına & & 15 & \\
\hline Bağçevanân ve suyolcu kullarına & & 115 & \\
\hline $\begin{array}{l}\text { Râmi Çiftliği kışlağında kapıcılar } \\
\text { kullarına }\end{array}$ & & 20 & \\
\hline İskemlecibaşı kullarına & & 10 & \\
\hline $\begin{array}{l}\text { Gülhâne kasr-ı hümâyunu bekçisi ve } \\
\text { neferâtı kullarına }\end{array}$ & & 44 & \\
\hline $\begin{array}{l}\text { Kozbekçi ve teberdaran-1 atik neferâtı ve } \\
\text { bazı kullara }\end{array}$ & & 3.000 & \\
\hline
\end{tabular}

Sultan Abdülaziz'in Velâdetinin Üçüncü Gününde Râmi Mevkib-i Hümâyununda Verilen İhsanlar

\begin{tabular}{|c|c|c|c|}
\hline Kime Verildiği & Nefer Sayısı & $\begin{array}{l}\text { Bir günlük ihsan } \\
\text { (kuruş) }\end{array}$ & $\begin{array}{l}\text { Bir aylık ihsan } \\
\text { (kuruş) }\end{array}$ \\
\hline Helvacı kullarına & & 33 & \\
\hline On aded kayıkçılar kullarına & & 100 & \\
\hline Tebdil uşakları & & 140 & \\
\hline Sayeban kullarına & & 125 & \\
\hline $\begin{array}{l}\text { Râmi Çiftliği kışlağında kapıcılar } \\
\text { kullarına }\end{array}$ & & 161 & \\
\hline Sancakdarlar kullarına & & 180 & \\
\hline ... saray hademeleri kullarına & & 261 & \\
\hline \multicolumn{4}{|c|}{ Sultan Abdülaziz'in Velâdetinin Hitâmında Verilen İhsanlar } \\
\hline Kime Verildiği & Nefer Sayısı & $\begin{array}{l}\text { Bir günlük ihsan } \\
\text { (kuruş) }\end{array}$ & $\begin{array}{l}\text { Bir aylık ihsan } \\
\text { (kuruş) }\end{array}$ \\
\hline Baş musahib ağa kullarına & & 150 & \\
\hline Sair musahib ağalar kullarına & & 700 & \\
\hline
\end{tabular}




\begin{tabular}{|l|r|r|}
\hline Baş çavuş ağa kullarına & 150 \\
\hline Sair çavuş ağaları kullarına & 700 & 400 \\
\hline Enderun mehter ağaları kullarına & 400 & 40 \\
\hline Birun mehterleri kullarına & 30 & 200 \\
\hline Hayalbazan kullarına & 150 & 20 \\
\hline Meddahan kullarına & 20 & \\
\hline Çengiyan kullarına & 20 & 20 \\
\hline Köçekler kullarına & 20 & \\
\hline Perdebazan kullarına & & \\
\hline Hokkabazan kullarına & & \\
\hline Kuklabazan kullarına & Kibtiyan çalgıcıları kullarına & \\
\hline
\end{tabular}

\begin{tabular}{|c|c|}
\hline \multicolumn{2}{|c|}{ Sultan Abdülaziz'in Velâdetinde Harem'e Teslim Edilen Eşyalar ${ }^{60}$} \\
\hline İsim & Aded/kita \\
\hline Pırlanta elmas ile müzeyyen maşallah & 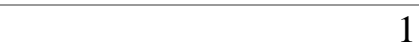 \\
\hline Pirlanta elmas ile müzeyyen mücerred zümrüd avize & 1 \\
\hline Pırlanta elmas ile müzeyyen zümrüd avize & 1 \\
\hline Pırlanta elmas ile müzeyyen kırmızı yakut avize & 1 \\
\hline Pirlanta elmas ile müzeyyen pîrûze avize & 1 \\
\hline Pirlanta elmasli horos mahmuzu & 1 \\
\hline Sim kaplama bağa & 1 \\
\hline Yaldızlı nuhas leğen & 1 \\
\hline Yaldizlı nuhas tas & 1 \\
\hline Yaldızlı nuhas abdest leğeni & 1 \\
\hline Sahtiyan mahfaza & 3 \\
\hline Kırmızı yakut yüzük & 1 (bahası 65) \\
\hline Pîrûze & 1 \\
\hline Şeşhane zümrüd & 1 \\
\hline Tahta zümrüd & 1 \\
\hline Maşallah pırlanta elmas bahası & 7.280 \\
\hline Zümrütlü avize pırlanta elmas bahası & 5.100 \\
\hline Avize pırlanta elmas bahası & 1.900 \\
\hline Kaplubağa sarf olunan sim & 88 \\
\hline Abdest leğeni yaldız bahası & 90 \\
\hline Şal takye & 10 \\
\hline Dülbend takye & 20 \\
\hline ... şal yorgan & 1 \\
\hline Kundak yorganı & 1 \\
\hline ... donluk şal ... & 2 \\
\hline Penbeli kışlık dülbend entari & 12 \\
\hline Penbeli kışlık dülbend içlik & 12 \\
\hline Penbeli dülbend etek bezi & 10 \\
\hline Penbeli dülbend kol bezi & 10 \\
\hline
\end{tabular}

60 TSMA, D. 239/1-3. 
Journal of Ottoman Civilization Studies

NO. 13 (2021), 60-82

N. Genç

\begin{tabular}{|l|r|}
\hline Penbeli dülbend ayak bezi & 10 \\
\hline Penbeli ... dülbend etek bezi & 20 \\
\hline Penbeli dülbend yorgan şiltesi & 2 \\
\hline Dülbend yorgan çarşab & 2 \\
\hline Dülbend minder şiltesi & 1 \\
\hline Beyaz gezi tob & 3 \\
\hline Al atlas minder & 1 \\
\hline Ceviz beşik & 1 \\
\hline Düz şal parçası & 1 \\
\hline .. donluk şal & 5 (top) \\
\hline Hindî düz dülbend & 2,5 top \\
\hline Kışlik dülbend & 4,5 \\
\hline Beyaz gezi & 5,5 \\
\hline Al atlas & 142 \\
\hline Bera-y1 mikdar kilabdanlı nimten & 13 \\
\hline Penbe ... & 212,5 \\
\hline Entariyesi & 55 \\
\hline Al atlas & \\
\hline
\end{tabular}




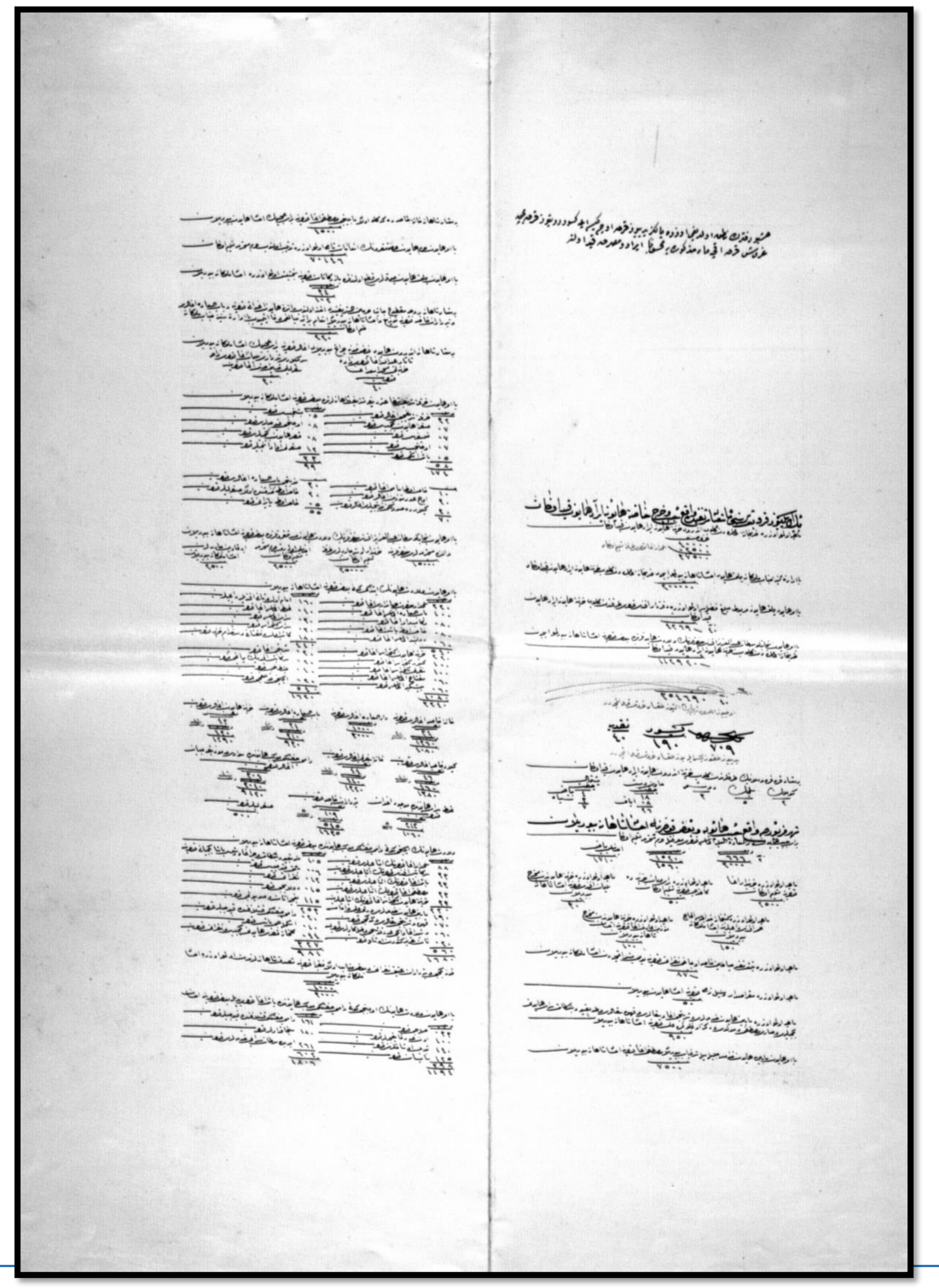


Journal of Ottoman Civilization Studies

NO. 13 (2021), 60-82

N. Genç

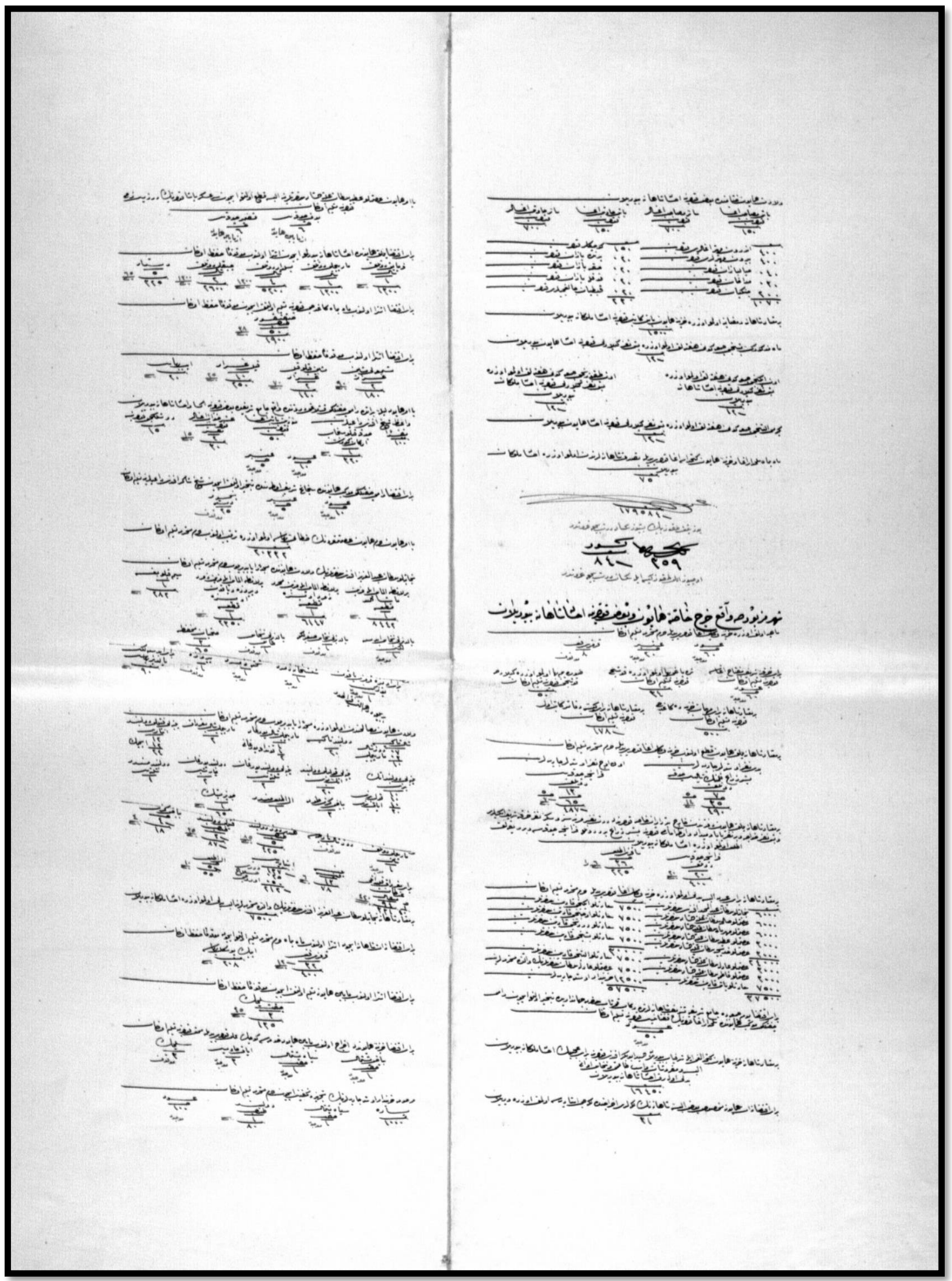


Journal of Ottoman Civilization Studies

NO. 13 (2021), 60-82

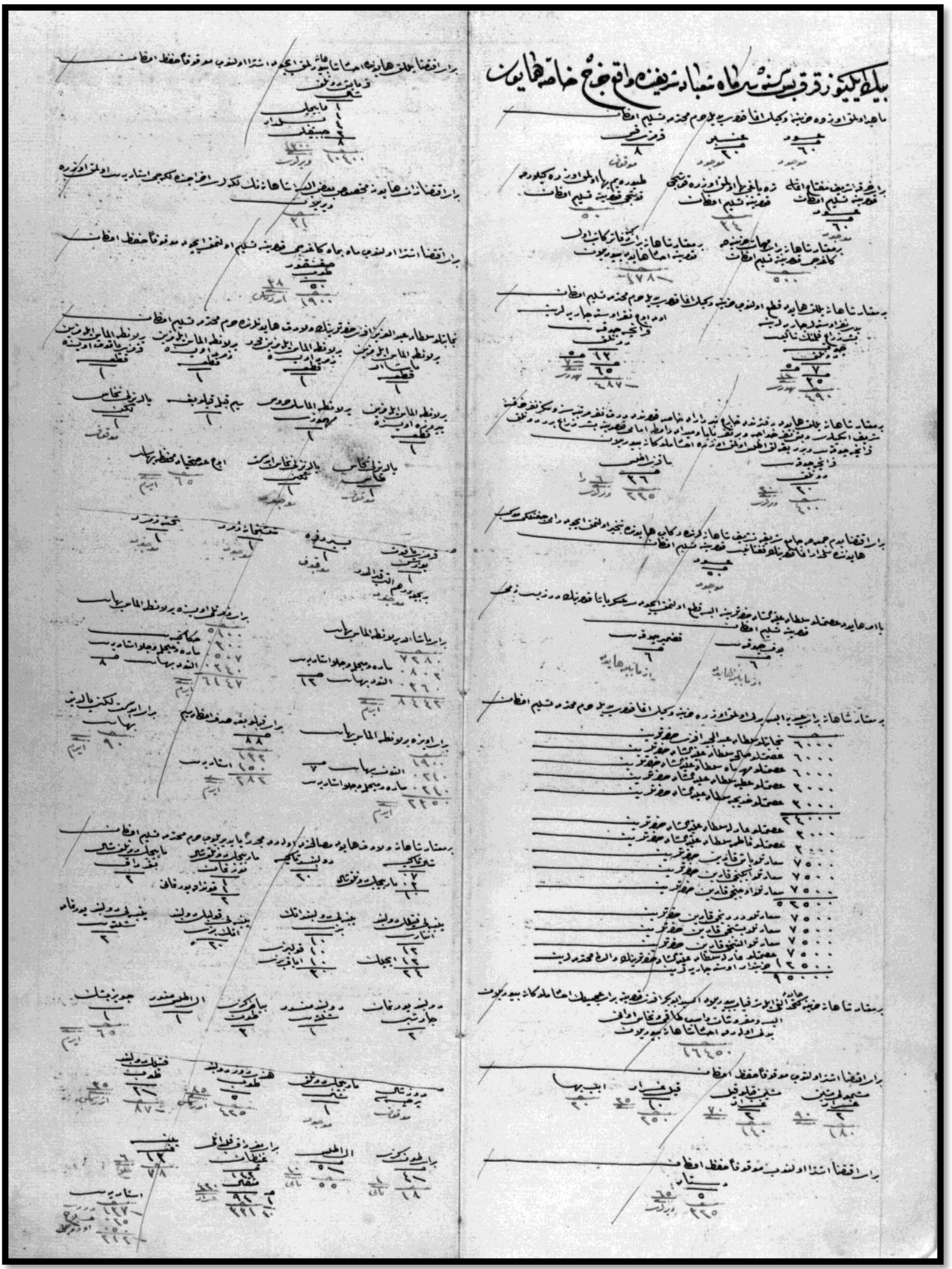


Journal of Ottoman Civilization Studies

NO. 13 (2021), 60-82

N. Genç

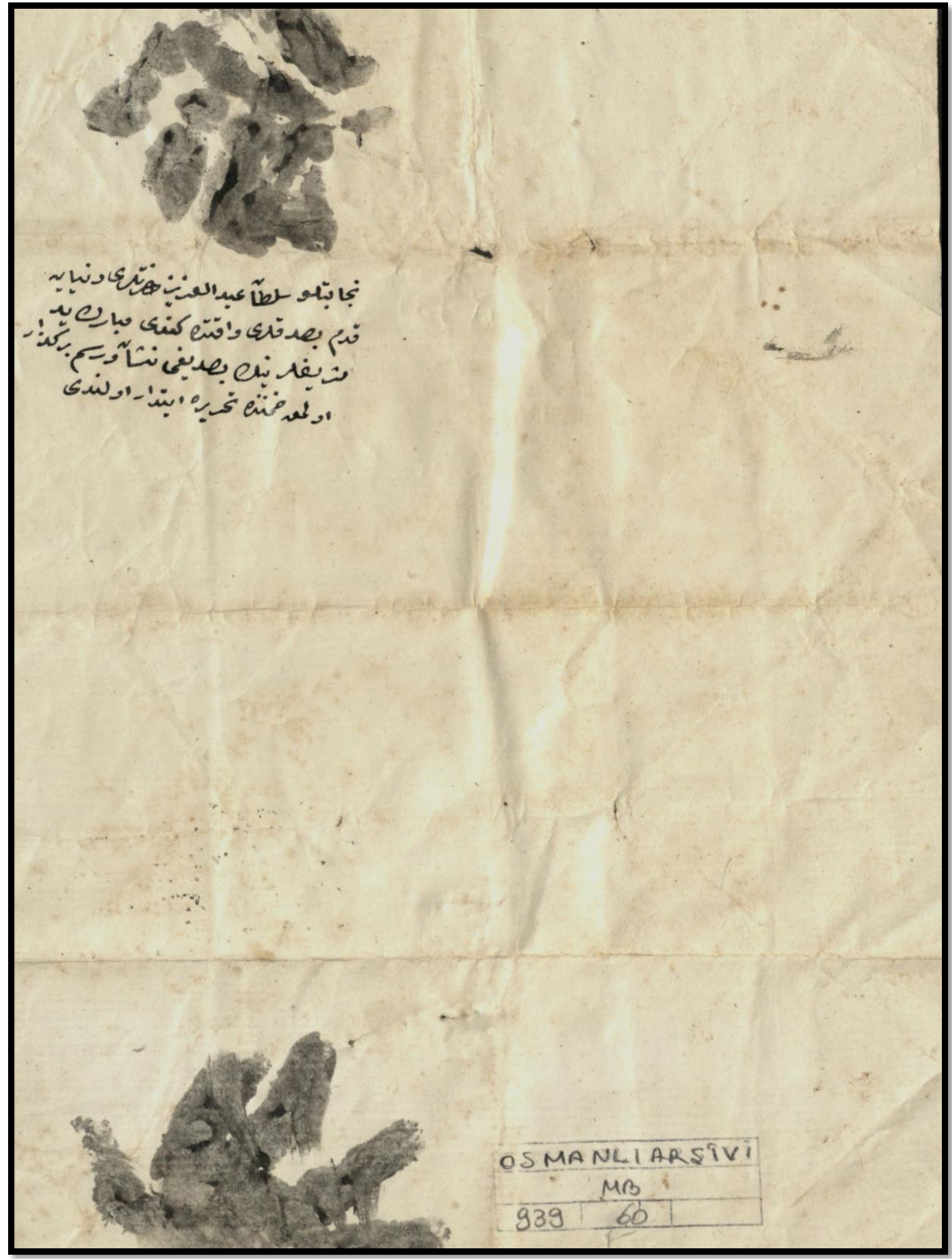


Journal of Ottoman Civilization Studies

NO. 13 (2021), 60-82

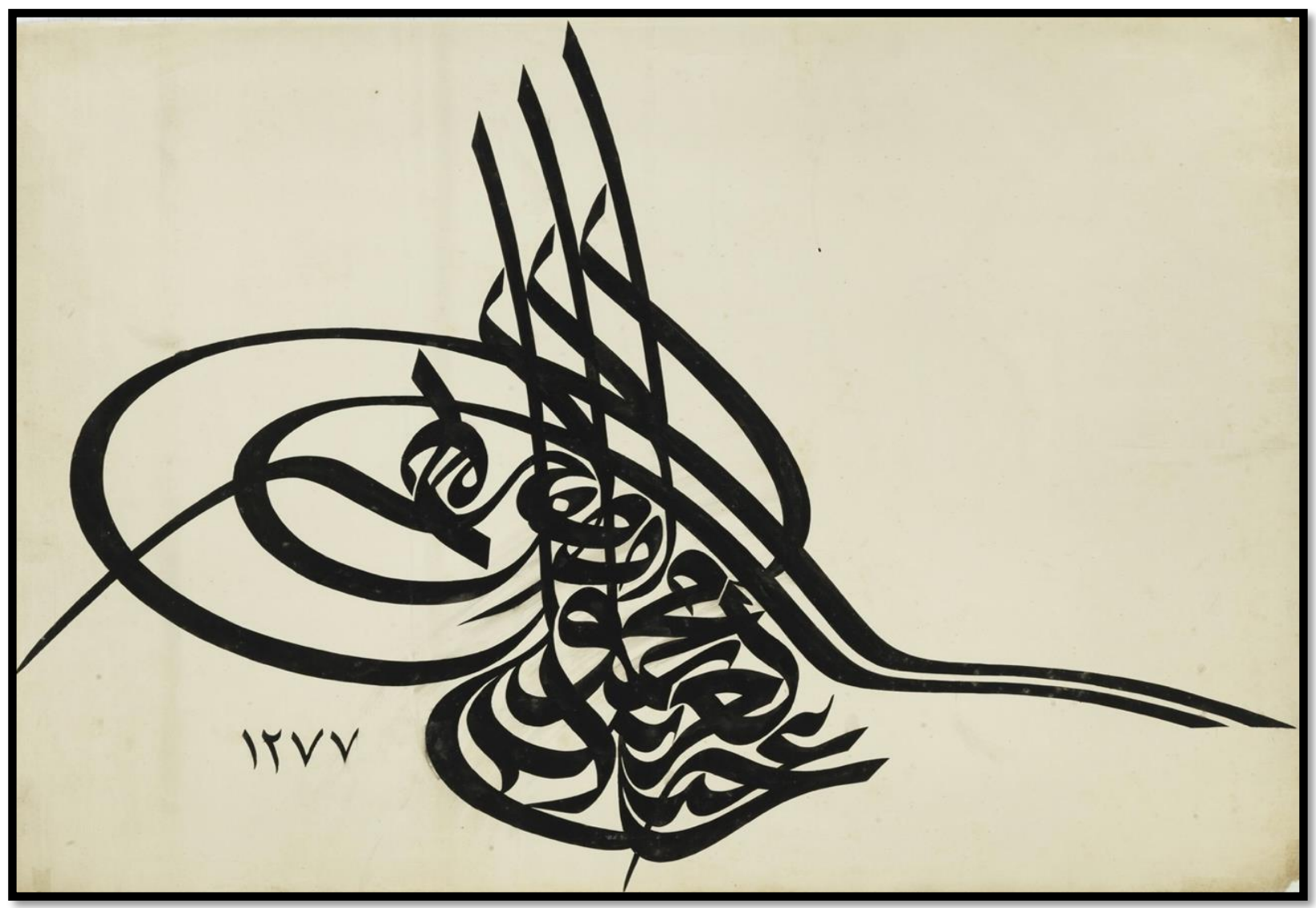

